\title{
Assesment of obesogenic factors in school-age children
}

\author{
Pınar Yılmazbaş ${ }^{1 \oplus}$, Gülbin Gökçay²ْ \\ ${ }^{1}$ Department of Pediatric, University of Health Sciences, Okmeydani Training and Research Hospital, Istanbul; ${ }^{2}$ Department of Social \\ Pediatrics, İstanbul University Institute of Child Health, İstanbul, Turkey.
}

\begin{abstract}
Background. The prevalence of obesity in childhood is increasing all over the world and the World Health Organization (WHO) regards obesity as one of the most important public health problems. The aim of our study was to investigate the changes in body mass index (BMI) in children between 6 and 11 years of age and to evaluate the factors affecting this change in two different schools.
\end{abstract}

Methods. We conducted a cross-sectional epidemiological study between January and March 2016 in two different schools. School age children from two different ages (6 and 11 years) participated in the study. Children's sociodemographic characteristics and daily habits were evaluated by a questionnaire. Weight, height, body fat ratio were measured.

Results. Of all 495 students, 270 were in the 6-year old group. According to BMI classification $21.2 \%$ of students were overweight and $14.5 \%$ obese. From 6 to 11 years of age percentages of overweight and obese students increased slightly $(1 \%)$. The mean daily screen time was high among overweight and obese students $(\mathrm{p}<0.05)$. The obesity rate (15.9\%) was higher in public school, than in private school $(6 \%)$. There was an obesogenic environment in the public school; sport facilities were limited, there was a canteen selling junk food and fizzy drink, but there was no free drinking water. Screen times of 11 year-old students were longer, and regular breakfast rates were lower than those of 6 year-old group $(\mathrm{p}<0.05)$.

Conclusions. In our study prevalence of obesity was $14.5 \%$, and overweight was $21.2 \%$. According to our findings obesogenic environment seemed to be a contributing factor of obesity. Screen time should also be considered in attempts to prevent obesity.

Key words: child, school age, obesity, obesogenic environment.

Obesity is an important public health problem that causes an increase in morbidity and mortality in childhood and adult age group. ${ }^{1}$ Worldwide obesity has nearly tripled since 1975 and 41 million children under the age of 5 years and over 340 million children and adolescents aged 5-19 years were reported to be overweight or obese in $2016 .^{2}$

According to Turkish Statistical Institute reports, obesity rates above 15 years old individuals

\ Pınar Yılmazbaş

drpinary@yahoo.com

Received 23rd March 2020, revised 31st May 2020 19th July 2020, accepted 17th August 2020.

This study was presented as an oral presentation in the 1 st International Eurasian Congress of Social Pediatrics. 28th November-1st December 2018, İstanbul, Turkey. were $19.9 \%$ in $2014 .^{3}$ According to childhood obesity surveillance initiative (COSI-TUR) 2016, $14.6 \%$ of 2 nd grade elementary school children were overweight, $9.9 \%$ of them were obese in Turkey. ${ }^{4}$

Childhood obesity substantially is exogenous as a consequence of urbanization, increased calorie intake and diminished physical activity. According to Centers for Disease Control and Prevention (CDC) reports obesity increases from preschool period to school ages., ${ }^{5,6}$ This slight increase by age is partly explained by some ultra-processed food consumption and dietary behaviors. ${ }^{78}$ Studies are needed about the epidemiology of obesity and the impact of factors especially those can be modified, such as obesogenic environment. 
The World Health Assembly welcomed the report of the Commission on Ending Childhood Obesity (ECHO) 2016 and its recommendations addresses the obesogenic environment and critical periods in the life course to tackle childhood obesity. According to ECHO, globalization and urbanization encourage obesity in all socioeconomic groups and children due to exposure to obesogenic environments. ${ }^{9}$

The aim of our study was to investigate the changes in body mass index (BMI) in children between 6 and 11 years of age, and to evaluate the factors affecting obesity, as well as to reveal the differences of environmental factors in two different schools.

\section{Material and Methods}

This cross-sectional epidemiological study was carried out in two schools, one was a private school representing high socioeconomic level, and the other was a public school representing middle and low socioeconomic level. Two different age groups (6 and 11 years) were included in the study.

Survey of Family Structure in Turkey 2011 content was used to question the socioeconomic level. Questions were developed with the help of a pediatric dietitian in creating the necessary items for evaluating the nutritional habits. By a questionnaire, information about the number of daily meals, breakfast habits, frequency and amount of consumption of snack foods and fizzy drinks, physical activity habits and daily and weekly screen time were asked. At the beginning of the study, a meeting was held in each school with school administration and council. The importance of the study was explained. At least $85 \%$ of the families filled the questionnaire forms in 4 days during the pilot study. Informed consent forms and questionnaires were delivered to the parents by class teachers 1 week before the measurements. The children whose parents agreed to participate in the study and filled the forms completely were included in the study. Height, weight and body fat ratios of each student were measured individually in a separate room.

Two schools were evaluated from the point of obesogenic environments during the study. This evaluation covered the type of food consumed during the school day, presence of gymnastic hall and free drinking water.

This is a social pediatrics doctoral thesis study.

This study was approved by the Istanbul University, Istanbul Medical School, Ethics Committee (approved number 25.01.2016-100).

Relevant permission was obtained at 04.12.2015, from Istanbul Governorship and Istanbul Provincial National Education Directorate.

All procedures performed in studies involving human participants were in accordance with the ethical standards of the institutional and/or national research committee and with the 1964 Helsinki declaration and its letter amendments or comparable ethical standards.

Informed consents were obtained from the patients and their parents according to institutional guidelines.

\section{Anthropometric Measurements}

All anthropometric measurements were carried out by one of the researchers with the help of a nurse. Height was measured using a portable stadiometer (SECA 213 Hamburg, Germany) recorded to an accuracy of $1 \mathrm{~mm}$. Weight was measured using the Tanita BC-601 (Tanita Corporation, Tokyo, Japan). Weight was recorded to within $0.1 \mathrm{~kg}$ and students were asked to take off their shoes and socks or tights. Percentage of body fat (BFP) was estimated from leg-to-leg with bioelectric impedance analysis (using the Tanita Body Composition Analyzer BC-601).

\section{Definitions}

Socioeconomic levels of participants were classified according to the Survey of Family Structure in Turkey 2011, developed by the 
Turkish Ministry of Family and Social Services. ${ }^{10}$ Parental education level, parental occupation and characteristics of the accommodation were questioned for this purpose. The socioeconomic levels were classified as low, middle and high according to the scores.

Consumption of junk food and fizzy drink was asked based on the frequency and amount of crisps, gumdrop, candy, wafer, cracker, biscuit, chocolate and fizzy drink intake in a week. Exercise habits were asked as; 'how many times did your child have at least 60 minutes of physical activity in the last 7 days?' and 'does he attend a sports activity regularly?'. Mode of travel to school (school service, walking, private car) was also asked.

Body mass index values were evaluated according to the percentiles of Turkish children. ${ }^{11}$ Values between 85 and 94 percentiles were classified as overweight and above 95 as obese. According to BFP curves of Turkish children, 85-94 percentiles were evaluated as overweight and over 95 was obese. ${ }^{12}$

\section{Statistical Analysis}

IBM SPSS Statistics 22 for statistical analysis (SPSS IBM, Turkey) programs were used for the analysis. Variables with normal distribution were evaluated by the Shapiro Wilks test. Kruskal Wallis and Mann Whitney U tests were used for quantitative variables. Qualitative variables were evaluated by Chi Square test.

\section{Results}

Of all students in public school $83.3 \%$ participated in the study, it was $67.7 \%$ in private school. In total, $80.8 \%$ of all students from two schools participated in the study. Recruitment of students are given in Figure 1.

Of 495 students in the study, 270 were in the 6-year old group, 225 were in the 11-year old group and $50.7 \%$ of them were female. Of all students, $50.9 \%$ were from low, $29 \%$ were from moderate socioeconomic level. The percentage of owning a mobile device was $43.0 \%$, having television in bedroom was $15.8 \%$. One third of the students ate junk food 1-2 times a week, $42.6 \%$ consumed fizzy drinks 1-3 times a week.

According to BMI classification $21.2 \%$ of the students were overweight and $14.5 \%$ obese. From 6 to 11 years of age percentages of overweight and obese students increased slightly (1\%) (Table I). The participants' BFP was compatible with BMI percentiles. Therefore, only BMI values were used in the continuation of the study.

Among 11-year old students, the proportion of owning mobile electronic devices or computers was higher than that of 6-year old students, the difference was statistically significant $(\mathrm{p}<0.05)$. In the 6-year old group, the rate of having daily breakfast was significantly higher than that of the 11-year old group $(\mathrm{p}<0.05)$ (Table II). The daily and weekly screen time averages of 11-

Table I. BMI distribution of all students.

\begin{tabular}{lccc}
\hline & & $\mathrm{n}$ & $\%$ \\
\hline BMI & Normal or low weight (all) & 318 & 64.2 \\
& 6 year-old & 176 & 65.2 \\
& 11 year-old & 142 & 63.1 \\
Overweight (all) & & 105 & 21.2 \\
& 6 year-old & 56 & 20.7 \\
& 11 year-old & 49 & 21.8 \\
Obese (all) & & 72 & 14.5 \\
& 6 year-old & 38 & 14.1 \\
& 11 year-old & 34 & 15.1 \\
\hline
\end{tabular}

BMI: body mass index 


\section{Private School}

All 40 students were 11 years old in $6^{\text {th }}$ class
Of 72 students in 1st class, 13 were under 6 years of age, 59 were eligible

34 students accepted to participate

67 students from private school were included

\section{Public School}

276 students in the $6^{\text {th }}$ class

11 students were older than 11 years old, 6 had chronic illness.

197 accepted to participate, 192 students completed the questionnaire
292 students in the $1^{\text {st }}$ class

33 were younger than 6 years, 4 had chronic diseases

240 accepted to participate, 236 students completed the questionnaire

428 students from public school were included

Fig. 1. Recruitment of children from two schools. 
Table II. Descriptive data of two age groups.

\begin{tabular}{llccc}
\hline & & $\begin{array}{c}6 \text { year-olds } \\
(\mathrm{n}=270) \\
\mathrm{n}(\%)\end{array}$ & $\begin{array}{c}11 \text { year-olds } \\
(\mathrm{n}=225) \\
\mathrm{n}(\%)\end{array}$ & $\mathrm{p}$ \\
\hline Owning mobile & Yes & $60(22.2 \%)$ & $153(68 \%)$ & 0.001 \\
device or computer & No & $210(77.8 \%)$ & $72(12 \%)$ & \\
Breakfast frequency & No breakfast & $4(1.5 \%)$ & $5(2.2 \%)$ & \\
& 1-3 times a week & $22(8.1 \%)$ & $49(21.8 \%)$ & 0.001 \\
& Most days of the week & $40(14.8 \%)$ & $55(24.4 \%)$ & \\
& Everyday & $204(75.6 \%)$ & $116(51.6 \%)$ & \\
\hline
\end{tabular}

Table III. Screen times of two age groups.

\begin{tabular}{lccc}
\hline & $\begin{array}{c}\text { 6 year-olds } \\
(\mathrm{n}=270) \\
\text { Mean } \pm \mathrm{SD}\end{array}$ & $\begin{array}{c}11 \text { year-olds } \\
(\mathrm{n}=225)\end{array}$ & $\mathrm{p}$ \\
\hline Mean $\pm \mathrm{SD}$ & \\
\hline Screen time during weekdays (hour) & $1.81 \pm 1.1$ & $2.42 \pm 1.2$ & 0.001 \\
Screen time during weekends (hour) & $3.16 \pm 2.04$ & $3.38 \pm 1.75$ & 0.094 \\
Average screen time (hour) & $2.27 \pm 1.32$ & $2.61 \pm 1.19$ & 0.001 \\
\hline
\end{tabular}

year old group were higher than those of the 6-year old group $(\mathrm{p}<0.05)$ (Table III).

Overweight and obese students, had longer screen time than those of normal and low weight students. This difference was statistically significant (Table IV).

Of all girls $24.7 \%$ were overweight and $13.1 \%$ obese. These figures were respectively $17.6 \%$ and $16 \%$ for boys. There was no statistically significant difference between genders.

All 67 students who were going to the private school, were at high socioeconomic level. Two hundred and fifty two (58.8\%) students going to public school were at low, 99 (23.1\%) were in the middle and $77(17.9 \%)$ were in the high socioeconomic level. There was no statistically significant difference between socioeconomic level and being obese and overweight among students of the public school.

At the public school there was no indoor sports hall, there was no physical education teacher for the 1st class students. Physical education classes were carried out in the outdoor playground if the weather was good. The 1st class students were bringing their food from home, 6th class students were buying from the school canteen. In the canteen there was junk food, fruit juices, sandwich, water, yogurt drink and fizzy drinks. There was no free drinking water at the public school. At the private school there was an indoor sports hall, indoor swimming pool and outdoor playground. There were physical education teachers for both 1st and 6th class students and all physical education classes were routinely carried out. There was no canteen at the private school, breakfast, lunch and a snack were given in the cafeteria under the control of a dietitian. There was free drinking water at the private school .

Obesity rates $(15.9 \%)$ were higher in students going to the public school than the private school (6\%) (Table V).

\section{Discussion}

In our study we evaluated school children in two age groups from two different schools in their school environment. This is one of the few studies in Turkey on the change of obesity frequency among school children and the factors 
Table IV. Screen time (hour) among obese, overweight and normal children.

\begin{tabular}{lcccc}
\hline \multicolumn{5}{c}{ BMI } \\
& $\begin{array}{c}\text { Normal or low weight } \\
(\mathrm{n}=318) \\
\text { Mean } \pm \text { SD }\end{array}$ & $\begin{array}{c}\text { Overweight } \\
(\mathrm{n}=105) \\
\text { Mean } \pm \text { SD }\end{array}$ & $\begin{array}{c}\text { Obese } \\
(\mathrm{n}=72) \\
\text { Mean } \pm \mathrm{SD}\end{array}$ & $P$ \\
\hline Daily screen time (hour) & $1.99 \pm 1.12$ & $2.27 \pm 1.18$ & $2.28 \pm 1.41$ & 0.030 \\
Weekend screen time (hour) & $3.17 \pm 1.98$ & $3.29 \pm 1.65$ & $3.62 \pm 1.95$ & 0.116 \\
Screen time a week (hour) & $2.32 \pm 1.25$ & $2.53 \pm .1 .14$ & $2.71 \pm 1.51$ & 0.029 \\
\hline
\end{tabular}

BMI: body mass index

Table V. Comparison of two schools according to BMI levels.

\begin{tabular}{lccc}
\hline BMI & $\begin{array}{c}\text { Public school } \\
(\mathrm{n}=428)\end{array}$ & $\begin{array}{c}\text { Private school } \\
\mathrm{n}(\%)\end{array}$ & $\begin{array}{c}\mathrm{n}=67) \\
\mathrm{n}(\%)\end{array}$ \\
\hline Normal or low weight & $268(62.6 \%)$ & $50(74.6 \%)$ & $\mathrm{p}$ \\
Overweight & $92(21.5 \%)$ & $13(19.4 \%)$ & 0.069 \\
Obese & $68(15.9 \%)$ & $4(6 \%)$ & \\
\hline
\end{tabular}

BMI: body mass index

influencing this change. We could not find any statistically significant change between 6 and11 years of age. We observed that the public school's environment was obesogenic and the number of obese and overweight students were higher in the public school.

WHO emphasizes that to successfully challenge childhood obesity; the obesogenic environment must be addressed. ${ }^{13}$ In the UK Biobank study, it was found that obesogenic environment accentuates the risk of obesity in genetically susceptible adults. ${ }^{14}$ Although the difference was not statistically significant, the obesity rate $(15.9 \%)$ was higher in the public school than the private school $(6 \%)$ (Table V). In the private school, there were both outdoor and indoor sports halls and an indoor swimming pool, but not in the public school. There was a physical education teacher for all the classes in private school, but there was only for 6th class students in the public school. Three meals were routinely given under the control of a dietitian and there was free drinking water at the private school, but these opportunities were not available at the public school. There was no canteen at the private school, but there was one at the public school. In previous studies it was found that higher consumption of water per weight was negatively associated with BMI and body fat, and obese children were less hydrated than normal peers, and they drink less water. ${ }^{15,16}$ Compatible to other studies, we saw that these environmental factors create an obesogenic environment inducing obesity. ${ }^{17-19}$

There are conflicting results in the literature about socio-economic level and frequency of obesity. This may be due to the insufficient classification of socioeconomic level and/or due to the economic state of country. ${ }^{20-23}$ Ozgüven et al. ${ }^{21}$ evaluated 680 adolescents and found no socioeconomic level difference in prevalence of overweight and obesity. In a study from Turkey, being a member of high-income family was stated as a risk factor for childhood obesity. ${ }^{22}$ Barriuso et al. ${ }^{20}$ evaluated 158 articles on the relationship between socioeconomic level and childhood obesity, and found an inverse relationship between socioeconomic level and weight status. In our study, we classified the socioeconomic level according to the Survey of Family Structure in Turkey and had a comprehensive evaluation of the socioeconomic 
level similar to the study of Barriuso et al. ${ }^{10,20}$ In our study we could not find a relation between socioeconomic level and obesity.

Previous studies showed that the presence of television in the bedroom as a risk factor to become obese. ${ }^{24,25}$ Nowadays children play games and spend time on social media on their mobile phones and tablets instead of watching television. ${ }^{26,27}$ The proportion of owning a mobile phone/tablet or computer was generally $43.0 \%$ in our study. In the six-year old group it was $22 \%$, and in the 11 -year old group $68 \%$ (Table II). Thus, screen time of 11-year old students were longer than the 6 year-old group, and this difference was statistically significant (Table III). The overweight and obesity prevalence according to BMI increased as screen time increased, and this was statically significant like other studies. ${ }^{28,29}$ (Table IV). Additionally, it was seen that one of the reasons of increased screen time was owning mobile devices as children get older. Intervention is needed at this point to decrease the screen time.

Unlike some studies, we could not find a correlation between skipping breakfast and obesity. ${ }^{29,30}$ However, $75.6 \%$ of the students from 6-year old group were having breakfast every day, and it was $51.6 \%$ in the 11 -year old group (Table II). The decline in the daily breakfast rates in the 11-year old group led us to think that as children grow up, their eating habits were changing in a wrong way.

There were some limitations of our study. The number of students from the private school was low. We could only measure the activity levels by self-report, and this may not reflect the true physical activity levels of the children.

In conclusion, our study was one of the few studies presenting important findings about the obesogenic school environment and obesity among students. Our findings led us think that the obesogenic school environment accentuates the risk of obesity; on the other hand, there was no single factor leading to obesity and many factors may interact with each other.

\section{Acknowledgement}

The authors would like to thank Professor Stuart Logan, who guided us about the methodology of the study and Professor Muazzez Garipağaoğlu who helped in creating the questionnaire form and conducting the study. We also thank the teachers, families and students who helped to perform the study.

\section{REFERENCES}

1. Ghagan S. Overweight and obesity. In: Kliegman RM, St Geme III JW, Blum NJ, Tasker RC, et al (eds) In: Nelson Textbook of Pediatrics. (21st edition) Vol 2 Philadelphia: Elsevier, 2020: 1876-1905.

2. World Health Organization 2020. Obesity and Overweight. Available at: https://www.who. int/news-room/fact-sheets/detail/obesity-andoverweight (Accessed on June 10, 2020).

3. Turkish Statistical Institute. 'Obesity prevalance in Turkey. 2015. Available at: https://tuikweb.tuik. gov.tr/basinOdasi/haberler/2017_31_20170607.pdf (Accessed on June 30, 2020).

4. T.C. Sağlık Bakanlığı. Türkiye Çocukluk Çağ1 (İlkokul 2. Sınıf Öğrencilerde) Şişmanlık Araştırması COSI-TUR 2016. Available at: https://hsgm.saglik. gov.tr/depo/haberler/turkiye-cocukluk-cagisismanlik/COSI-TUR-2016-Kitap.pdf (Accessed on June 10, 2020).

5. Centers for Disease Control and Prevention. Overweight and Obesity. Available at: https://www. cdc.gov/obesity/data/childhood.html (Accessed on June 10, 2020).

6. Freitas $\mathrm{Al}$, Moreira $\mathrm{C}$, Santos AC. Time trends in prevalance and incidence rates of childhood overweight and obesity in Portugal: generation XXI birth cohort. Int J Obes (Lond) 2019; 43: 424-427.

7. Costa CS, Rauber F, Leffa PS, Sangalli CN, Campagnolo PDB, Vitolo MR. Ultra-processed food consumption and its effects on anthropometric and glucose profile: a longitudinal study during childhood. Nutr Metab Cardiovasc Dis 2019; 29: 177184.

8. Gingras V, Rifas-Shiman SL, Taveras EM, Oken E, Hivert MF. Dietary behaviors throughout childhood are associated with adiposity and estimated insulin resistance in early adolescence: a longitudinal study. Int J Behav Nutr Phys Act 2018; 15: 129.

9. World Health Organization 2016. Commission on Ending Childhood Obesity. Available at: https:// www.who.int/end-childhood-obesity/news/launchfinal-report/en/ (Accessed on June 10, 2020). 
10. T.C. Aile ve Sosyal Politikalar Bakanlığı. Türkiye Aile Yapısı Araştırması TAYA 2011. Available at: https://ailevecalisma.gov.tr/uploads/athgm/ uploads/pages/indirilebilir-yayinlar/65-aile-yapisiarastirmasi-2011.pdf (Accessed on June 10, 2020).

11. Bundak R, Furman A, Gunoz H, Darendeliler F, Baş F, Neyzi O. Body mass index references for Turkish children. Acta Paediatr 2006; 95: 194-198.

12. Kurtoğlu S, Mazicioğlu MM, Öztürk A, Hatipoğlu N, Çiçek B, Üstünbaş HB. Body fat reference curves for healthy Turkish children and adolescents. Eur J Pediatr 2010; 169: 1329-1335.

13. World Health Organization 2015. Draft Final Report of the Commission on Ending Childhood Obesity. Available at: https://www.who.int/end-childhoodobesity/commission-ending-childhood-obesitydraft-final-report-en.pdf (Accessed on June 10, 2020).

14. Tyrrell J, Wood AR, Ames RM, et al. Gene-obesogenic environmet interactions in the UK Biobank study. Int J Epidemiol 2017; 46: 559-575.

15. Milla-Tobarra M, García-Hermoso A, Lahoz-García $\mathrm{N}$, et al. The association between water intake, body composition and cardiometabolic factors among children-The Cuenca study. Nutr Hosp 2016; 33(Suppl 3): 312.

16. Maffeis C, Tommasi M, Tomasselli F, et al. Fluid intake and hydration status in obese vs normal weight children. Eur J Clin Nutr 2016; 70: 560-565.

17. Staiano AE, Baker CM, Calvert SL. Dietary digital diaries: documenting adolescents' obesogenic environment. Environ Behav 2012; 44: 695-712.

18. Carter MA, Swinburn B. Measuring the "obesogenic" food environment in New Zealand primary schools. Health Promot Int 2004; 19: 15-20.

19. Li M, Dibley MJ, Yan H. School environment factors were associated with BMI among adolescents in Xi'an City China. BMC Public Health 2011; 11: 792.

20. Barriuso L, Miqueleiz E, Albaladejo R, Villanueva R, Santos JM, Regidor E. Socioeconomic position and childhood-adolescent weight status in rich countries: a systematic review, 1990-2013. BMC Pediatr 2015; 15: 129
21. Ozgüven I, Ersoy B, Ozgüven AA, Erbay PD. Evaluation of nutritional status in Turkish adolescents as related to gender and socioeconomic status. J Clin Res Pediatr Endocrinol 2010; 2: 111-116.

22. Bereket A, Atay Z. Current status of childhood obesity and its associated morbidities in Turkey. J Clin Res Pediatr Endocrinol 2012; 4: 1-7

23. Bhurosy T, Jeewon R. Overweight and obesity epidemic in developing countries: a problem with diet, physical activity or socioeconomic status? ScientificWorldJournal 2014; 2014: 964236.

24. Barr-Anderson DJ, van den Berg P, NeumarkSztainer D, Story M. Characteristics associated with older adolescents who have a television in their bedrooms. Pediatrics 2008; 121: 718-724.

25. Hancox RJ, Milne BJ, Poulton R. Association between child and adolescent television viewing and adult health: a longitudinal birth cohort study. Lancet 2004; 364: 257-262.

26. Bassett DR, John D, Conger SA, Fitzhugh EC, Coe DP. Trends in physical activity and sedantary behaviors of United States Youth. J Phys Act Health 2015; 12: 1102-1111

27. Sugimori H, Yoshida K, Izuno T, et al. Analysis of factors that influence body mass index from ages 3 to 6 years: a study based on the Toyama cohort study. Pediatr Int 2004; 46: 302-310.

28. Reilly JJ, Armstrong J, Dorosty AR, et al; Avon Longitudinal Study of Parents and Children Study Team Early life risk factors for obesity in childhood: cohort study. BMJ 2005; 330: 1357.

29. Rathnayake KM, Roopasingam T, Wickramasighe VP. Nutritional and behavioral determinants of adolescent obesity: a case-control study in Sri Lanka. BMC Public Health 2014; 14: 1291.

30. Smetanina $\mathrm{N}$, Albaviciute E, Babinska V, et al Prevalence of overweight/obesity in relation to dietary habits and lifestyle among 7-17 years old children and adolescents in Lithuania. BMC Public Health 2015; 15: 1001. 